\title{
The period between beta-blocker use and physical activity changes training heart rate behavior
}

\author{
Naiane Ferraz Bandeira Alves, Suênia Karla Pacheco Porpino, Alexandre Sérgio Silva*
}

\author{
Laboratory of Study of Physical Training Applied to Performance and Health, University Federal of Paraiba.
}

\begin{abstract}
The Brazilian Society of Cardiology (SBC) proposes that hypertensive subjects who use beta-blockers and practice physical exercises must have their training heart rate (HR) corrected due to the negative chronotropic effect of this drug. Nevertheless, if the physical activity is performed outside of plasmatic half-life, correction may not be necessary. This study investigated the exercise chronotropic response both inside and outside the beta-blocker plasmatic half-life. Nine subjects in use of atenolol or propranolol, and six controls, carried out three walking sessions in three days according to different schedules: EX2 (two hours after drug administration, at the plasmatic peak); EX11 (eleven hours after drug administration, at the end of plasmatic half-life); and EX23 (twenty-three hours after drug administration, outside the plasmatic half-life. The walking sessions were performed on an ergometric treadmill and HR was monitored by a heart rate monitor. During the exercises, mean HRs were 97.2, 108.4 and 109 for EX2, EX11 and EX23, respectively, with the value for EX2 statistically lower than the others $(\mathrm{p}<0.05)$. There were no statistical differences in the control group $(p>0.05)$. The study concludes that the attenuation of the positive chronotropic response which occurs during exercise in subjects using beta-blockers, is less evident when the exercise is performed outside the plasmatic half-life of the drug.
\end{abstract}

Uniterms: Beta-blockers/negative chronotropic effect. Atenolol. Propanolol. Hypertension. Physical exercise. Training heart rate/control.

\begin{abstract}
A Sociedade Brasileira de Cardiologia (SBC) propõe que os hipertensos que utilizam beta-bloqueadores e praticam exercícios físicos devem ter sua frequência cardíaca de treinamento (HR) corrigida devido ao efeito cronotrópico negativo desse fármaco. Contudo, se a atividade física é realizada fora da meia-vida plasmática do fármaco, a correção pode não ser necessária. Este estudo investigou a resposta cronotrópica ao exercício dentro e fora da meia-vida plasmática do beta-bloqueador. Nove indivíduos que usavam atenolol ou propranolol e seis controles, efetuaram três sessões de caminhada em três dias, de acordo com diferentes esquemas: EX2 (duas horas após a administração do fármaco, no pico plasmático); EX11 (11 horas após a administração do fármaco, no fim da meia-vida plasmática) e EX23 (23 horas após a administração do fármaco, fora da meia-vida plasmática). As caminhadas foram realizadas em esteira ergométrica e a HR foi monitorada por monitor de freqüência cardíaca. Durante os exercícios, as HR médias foram de 97,2, 108,4 e 109, para EX2, EX11 e EX23, respectivamente, com valor de EX2 estatisticamente mais baixo do que os outros $(p<0,05)$. Não houve diferenças estatísticas no grupo controle $(\mathrm{p}>0,05)$. O estudo conclui que a atenuação da resposta cronotrópica positiva, que ocorre durante o exercício em indivíduos que utilizam beta-bloqueadores, é menos evidente quando o exercício é realizado fora da meia-vida plasmática do fármaco.
\end{abstract}

Unitermos: Beta-bloqueadores/efeito cronotrópico negativo. Atenolol. Propranolol. Hipertensão. Exercício Físico. Freqüência cardíaca de treinamento/controle.

\section{INTRODUCTION}

The practice of regular physical activity is an important tool in the prevention and non-pharmacological treatment of hypertension. Physical activity prescription

*Correspondence: Alexandre Sérgio Silva. R. Monteiro Lobato, 501/408, Tambaú - João Pessoa-PB - CEP: 58039-170. E-mail: ass974@yahoo.com.br must be done with caution, especially when the patient has other concomitant morbidities such as angina and heart failure. In addition to these patients being more sensitive to cardiovascular changes during their workout, they may present reduced physical performance (Baster, Basterbroks, 2005; Suzuki, Ohta, 2008; Thompson, 2004).

An important aspect that must be considered in physical exercise prescription is the relationship between 
effectiveness and safety, with intensity being one of the main variables involved in assuring this balance. Intensities that are too low render the exercise ineffective, since it does not trigger the cardiovascular adaptations that improve the subject's health. If the intensity is very high however, there is an increase in the risk of cardiovascular accidents during the exercise (Nelson et al., 2007; Nóbrega et al., 1999).

Heart rate monitoring is the most common method for supervision of exercise intensity. The efficacy and safety of aerobic exercise is guaranteed while training with a heart rate of between 60 and $85 \%$ of maximal reserve heart rate. This rate is called the target-zone (SBC, 2006).

However, some factors may change the heart rate. Beta-blockers (BB) are substances that inhibit the $\beta$-adrenergic receptors, promoting a negative chronotropic action, observed at rest and during exercise. This is characterized by a lower heart rate for the same effort intensity, in comparison to a situation of drug abstinence (Koshucharova et al., 2001). These drugs are divided into three categories: non-selective beta-blockers called firstgeneration BBs which block receptors from the subtypes called $\beta 1$ and $\beta 2$-adrenergic; second-generation BBs, which have selective action on the $\beta 1$ receptor; and thirdgeneration $\mathrm{BBs}$ that, besides $\beta$-adrenergic blockade, have a vessel expanding action (Pereira-Barreto, 2004; Firmida, Mesquita, 2001; Pedersen, Cockcroft, 2007).

Due to the slower increase of heart rate during exercise, the Brazilian Society of Cardiology (1997) suggests the use of an equation to correct heart rate values when using this variable to monitor exercise intensity. Another recommended method in physical exercise prescription to these patients is training heart rate determination through the ergometer test while under the effect of BB (Vanzelli et al., 2005).

Nevertheless, neither the correction equation suggested by the SBC nor the ergometer test under the effect of BB consider absorption time, plasmatic half-life, or substance elimination time. Likewise, they do not consider the time elapsed between administration of the BB and the time that the hypertensive subject performs physical exercise. The negative chronotropic effect magnitude may vary throughout the day once its concentration peak is obtained (approximately one hour after drug ingestion), according to the BB pharmacokinetic. In addition, the plasmatic halflife varies from one to six hours (Couto, 1998). However, depending on when the subject performs the physical exercise, its prescription with either equation use or the ergometer test under the BB effect might be misleading.

Considering these factors, this study tested the hypothesis that the negative chronotropic effects of atenolol and propranolol at rest, as well as the attenuation of the positive chronotropic effect of the exercise promoted by these drugs, vary after administration, according to the pharmacodynamics. In this sense, the present study can contribute with important information to the establishment of an ideal and safe heart rate zones for hypertensive patients, as well as pave the way for new studies, given that few studies have investigated the implications of betablocker use in physical exercise prescription.

\section{MATERIAL AND METHODS}

\section{Study subjects}

This study project was submitted to the Ethics Committee of the Health Science Center of the Federal University of Paraíba, and was approved under the 1200/07 Protocol. The subjects were selected, intentionally, at the locations where they practiced walking. After an explanation of the research objectives and procedures, those who agreed to participate were asked to sign a written informed consent form.

Nine hypertensive subjects were selected, including seven females, with mean age of 53.9 years $( \pm 2.8)$, and without renal dysfunction history. Participants had to be physically active and practicing aerobic exercises for at least three months, on a weekly basis, for three to five days a week. They were required to use an adrenergic beta-blocker drug in one daily dose, and administer the drug only in the first hours of the morning. Seven out of nine subjects used atenolol, and two used propranolol at doses of 25, 40 and $50 \mathrm{mg}$.

The control group comprised six hypertensive women, not in use of BB, with a mean age of 57.4 years $( \pm$ 5.5), who were physically active and fulfilled to the same criteria as the experimental group regarding the way they exercised. Three subjects used alpha central agonist, two used an inhibition agent of angiotensine conversion enzyme, and one used an antagonist of AT1 receptors. After signing the informed consent form, their dates and times of walking were registered. To standardize data collection time points, all subjects were asked to administer the drug at seven o'clock in the morning. This time was confirmed by the subjects' declaration for each day in which data were collected.

\section{Study design}

Each subject carried out three walking sessions of forty minutes in duration on alternate days. Three different times were adopted for each day, considering both 
the time of plasmatic half-life of the beta-blocker drug and the point of maximum plasmatic concentration peak. Beta-blocker plasmatic half-life is, on average, six hours with a concentration peak of about two hours. Considering that the subjects took the drug at 7:00 a.m., the exercise was practiced two hours (EX2), eleven hours (EX11) and twenty-three (EX23) after drug administration. The same procedure was used for the control group, as was the order in which the exercises were performed.

\section{Physical Activity Sessions}

Before and immediately after each exercise session, the blood pressure of each subject was measured by the auscultatory method, following the protocol recommended by the SBC (2006). The first session conducted was at the EX2 point. The subjects carried out a walking exercise on a Proaction treadmill, with a minimum velocity control of $0.1 \mathrm{~km} / \mathrm{h}$ and a maximum velocity of $16 \mathrm{~km} / \mathrm{h}$. The exercise duration was forty minutes, with an intensity of between 60 to $80 \%$ of the maximal reserve heart rate. A period of five minutes was adopted in order to allow the treadmill velocity to reach a heart rate compliant with the determined intensity, after which a chronometer was used to register the forty minutes of exercise. The treadmill velocity in which the heart rate stabilized itself in a training zone was registered.

For the EX11 and EX23 sessions, the intensity determined was the same velocity obtained in the EX2 session. This procedure was adopted to guarantee that the subjects would do the three sessions with uniform effort intensity, in such a way as to permit study of possible heart rate changes in response to $\mathrm{BB}$ administration.

A heart rate zone compatible with the training target zone was determined for the first day of physical exercise (EX2), based on the Karvonen equation (1957), defined as follows:

$$
\mathrm{THR}=\mathrm{HRR}+\% \text { training }(\mathrm{MHR}-\mathrm{HRR})
$$

where:

THR $=$ Training heart rate;

$\mathrm{HRR}=$ heart rate at rest

MHR = Maximal heart rate;

$\%$ training $=$ training intensity percentage

The heart rate at rest was measured after the subjects had sat down for ten minutes. For the maximal heart rate estimation, we used the Bruce equation (1974) which is designed especially for the hypertensive population
(Bruce et al, apud Robergs and Landwehr, 2002), as follows:

$$
\text { MHR }=204-1.07 \times \text { age }
$$

where:

MHR = estimated maximum heart rate

Additionally, the training heart rate correction equation for subjects who used BB is as follows:

$$
\% \text { reduction }=(\mathrm{Y}+95.58) / 9.74
$$

where:

$\%$ reduction $=$ Reduction percentage

$\mathrm{Y}=$ Drug dose $(\mathrm{mg})$

During each of the three exercise sessions, the heart rate was measured every two minutes, using an Oregon Scientific heart rate monitor with one beat per minute precision.

The exercise sessions were conducted in a controlled environment, with temperature of $25^{\circ} \mathrm{C}$, measured by a West Germany thermometer, at a relative air humidity of $75 \%$, as registered by a G. Huger hygrometer.

The subjects were asked not to do any additional physical exercise during this study data collection phase. Moreover, the subjects were asked to take their medication as normal on the days between sessions. For the EX23 session, the subjects were requested to bring their medicines to the research site, in order to guarantee that it would be administered at 7:00 a.m., thereby maintaining their daily routine as well as remaining in compliance the methodological patterns of the study.

\section{Data Analysis}

Data are expressed as mean and standard deviation. The Smirnov-Kolmogorov test was used to test data normality, using a significance level of $5 \%$. As this procedure indicated that the data did not conform to the Gauss curve, a Kruskal-Wallis test was then performed to examine the differences between the mean heart rates during exercises EX2, EX11 and EX23 (with a confidence level of 5\%). These procedures were developed with the aid of an Excel 2003 spreadsheet and the statistical software SPSS 13.0.

\section{RESULTS}

The blood pressure at rest for the EX2 session was 
$126.5 \pm 7 \mathrm{mmHg}$ for the systolic, and $77.5 \pm 8 \mathrm{mmHg}$ for the diastolic rates. For EX11, the values of systolic and diastolic blood pressure were $130 \pm 7 \mathrm{mmHg}$ and $82 \pm 7 \mathrm{mmHg}$, respectively. The respective values for EX23were $129 \pm 7 \mathrm{mmHg}$ and $82 \pm 8 \mathrm{mmHg}$. At the end of the exercise, the subjects showed an increase in systolic pressure of $12.7 \pm 7 ; 14 \pm 7$; and $8 \pm 7 \mathrm{mmHg}$ for the at rest values of EX2, EX11 and EX23, respectively. The variations of the systolic pressure for these same sessions were $2.0 \pm 5 ;-3.3 \pm 4$; and $4.7 \pm 2 \mathrm{mmHg}$.

Table I presents the heart rate at rest of the subjects over the three days of physical exercise. The statistical test revealed that there was no significant difference between the values of heart rate in the three situations $(p>0.05)$.

TABLE I - Mean values for heart rate at rest, verified immediately before the three physical exercise sessions. There was no statistical difference among the procedures EX2, EX11 and EX23. (HRR-BB = heart rate at rest of the experimental group; HRR-CONT = heart rate of the control group; EX2 = physical exercise two hours after drug administration; EX11= physical exercise eleven hours after drug administration; EX23 = physical exercise twenty-three hours after drug administration)

\begin{tabular}{lcc}
\hline & HRR-BB (spm) & HRR-CONT \\
\hline EX2 & $62( \pm 6.8)$ & $82.7( \pm 5.9)$ \\
EX11 & $64( \pm 7.9)$ & $78.2( \pm 5.3)$ \\
EX23 & $64.2( \pm 8.9)$ & $80.2( \pm 8.0)$ \\
\hline
\end{tabular}

The behavior during the physical exercise is shown in FIGURE 1. A significantly lower heart rate was observed during the exercise carried out in the plasmatic concentration peak of $\mathrm{BB}(\mathrm{EX} 2)$, compared to EX23, when the subjects had not yet administered the drug that day. It also differed from EX11, when the active substance was already being excreted from the subjects' body, according to the BB pharmacodynamics (Couto, 1998). The difference between the sessions EX2 and EX23 was $10.9 \%$, while in EX11, there was a reduction of $10.3 \%$.

In contrast to the results found in the BB group, the subjects of the control group exhibited responses similar to the heart rate at rest at ten, twenty, thirty and forty minutes of exercise, with no statistical differences between the HR measures among the three exercise sessions. Results are shown in Figure 2.

Absolute variation of heart rate during exercise was observed by subtracting the mean values at ten, twenty, thirty and forty minutes from the basal values. Figure $3 a$, shows results in the experimental group, where a statistically significant difference was observed at ten, twenty and thirty minutes of exercise in the sessions EX11 and

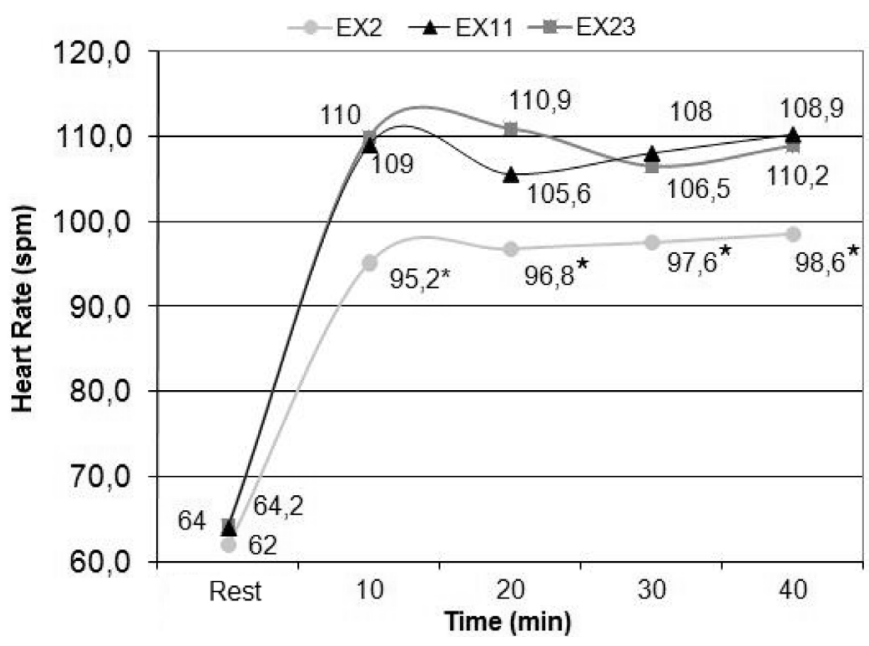

FIGURE 1 - Mean behavior of heart rate at rest, at ten, twenty, thirty and forty minutes of exercise during the three exercise procedures (asterisks indicate differences between HR values of procedure EX2, EX11 and EX23 (p<0.05); EX2 = physical exercise two hours after drug administration; EX11= physical exercise eleven hours after drug administration; EX23 = physical exercise twenty-three hours after drug administration.).

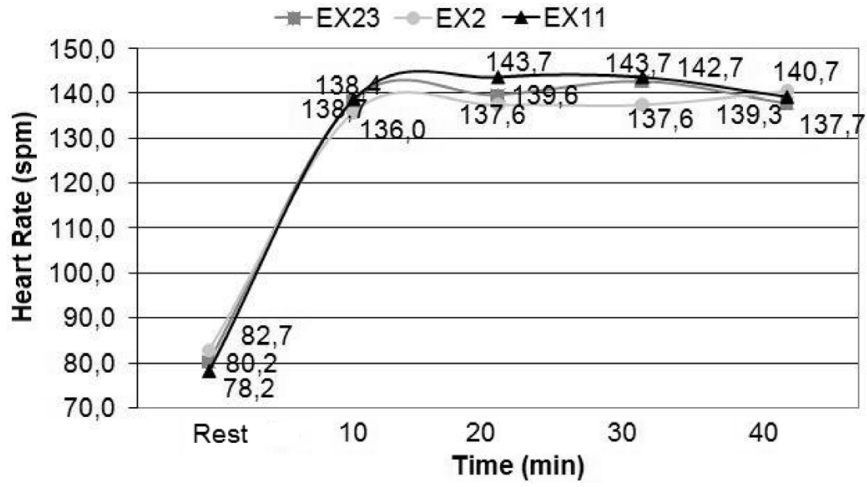

FIGURE 2 - Mean behavior of heart rate at ten, twenty, thirty and forty minutes of exercise during the three exercise procedures in the control group. (There was no statistical difference for the heart rates at any of the time points in the three exercise sessions $(\mathrm{p}>0.05)$; EX2 = physical exercise two hours after drug administration; EX11 = physical exercise eleven hours after drug administration; EX23 = physical exercise twenty-three hours after drug administration).

EX23, compared to session EX2 ( $p<0.05)$. No significant difference in the absolute variation of heart rate was found among the three sessions in the control group $(\mathrm{p}>0.05)$.

\section{DISCUSSION}

The present study data confirm previous information that the BB drug provokes changes in the heart rate which interfere in the chronotropic response during physical exercise (Wonisch et al., 2003; Stoschitzky et al., 2006; 


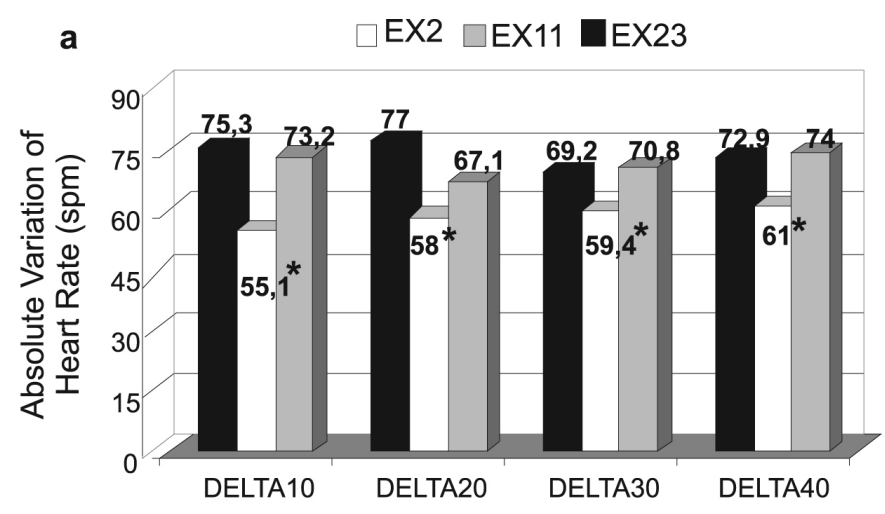

b

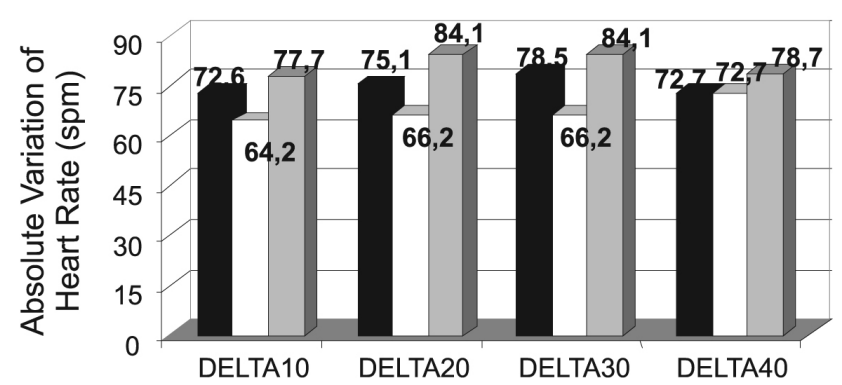

FIGURE 3 - Absolute variation of exercise heart rate for the heart rate at rest at ten, twenty, thirty and forty minutes of exercise during the three procedures in the experimental group (a) and in the control group (b). EX2 = physical exercise two hours after drug administration; EX11 = physical exercise eleven hours after drug administration; EX23 = physical exercise twenty-three hours after drug administration).

Stoschitzky et al., 2004; Derman et al., 1993; Pokan et al., 1999; Van Baak, 1988; Tesch, 1985). Nevertheless, this study demonstrates for the first time that the chronotropic change induced by beta-blockers does not persist throughout the day after being administered, but instead is attenuated when the exercise is performed outside the BB's plasmatic half-life.

The subjects' arterial pressure was found to be lower at the EX2 point, when the drug had reached its plasmatic half-life. Although higher than during the other two points, these values were always controlled within the parameters of $140 / 90 \mathrm{mmHg}$, as recommended by the SBC (1997). Although the exercise had been performed both in and outside of beta-blocker plasmatic half-life, the arterial pressure response was considered physiological in the three exercise sessions.

The control of the treadmill walk velocity, room temperature and the relative air humidity eliminates the possibility that these variables influenced the heart rate differences that were found in the session EX2 (compared to EX11 and EX23). The control group data confirm that this heart rate variation did not occur due to metabolic, neural or hormonal oscillations, but instead resulted from the time of day the three exercise sessions were performed.

Derman et al. (1993) reported that atenolol and propranolol reduced the heart rate in physical exercise by $21.9 \%$ and $14.6 \%$, respectively, in comparison to other similar exercise sessions conducted without using these drugs. These values are greater than the $10.9 \%$ and $10.3 \%$ heart rate reduction in the exercises performed at eleven and twenty-three hours after the drug was ingested, compared to the exercise performed two hours after BB administration (plasmatic half-life period) in the present study. This smaller chronotropic attenuation may have occurred because of the fact that, in the exercises EX11 and EX23, the subjects were still under some BB effect, even though this was outside the plasmatic half-life period. Nonetheless, this confirms the hypothesis that the chronotropic change induced by BB in exercise depends on the time of drug administration and the time chosen to perform the exercise.

Concerning cardiovascular safety, these results showed that $100 \%$ of the subjects were kept within the training zone during the exercise in the EX2 procedure (which had the prescription corrected for the BB use). In the procedures EX11 and EX23 however, $40 \%$ of the subjects exceeded the target-zone values. Therefore, the present study highlights that the correction equation use must be adjusted for time elapsed between drug administration and the beginning of physical exercise.

According to Tabet et al. (2006), the use of the physical exercise prescription method by means of generic equations can be misunderstood by subjects who use beta-blockers. The most common prescription method by professionals is the use of an ergometer test with those subjects using BB. From the study results, it is recommended that exercise is prescribed only based on hypertensive subjects using this drug daily (Vanzelli et al., 2004). Nonetheless, this policy is also insufficient given that the patient may not perform the exercise at the same time point after drug administration that the ergometer test was conducted. Thus, this procedure proved to be flawed as a correction equation, in that it overlooks the time interval between drug administration and time of exercise.

Monitoring of heart rate during physical exercise is one of the most common methods among physical educators, while beta-blockers are one of the most prescribed anti-hypertensive drugs by physicians. The high prevalence of subjects who combine $\mathrm{BB}$ and physical exercise increases highlights the importance of this study. Against this background, it is recommended that these findings be widely disseminated among physicians and physical educators. 
Bearing in mind that this is the first study to examine the drug's use in relation to time elapsed between administration and beginning of exercise, and taking into consideration the large hypertensive population that uses $\mathrm{BB}$, it is recommended that further research be conducted to increase the knowledge base regarding this phenomenon. Several studies have shown that third-generation BBs have less impact on heart rate and, consequently, on exercise tolerance (Weiss, 2006; Veverka et al., 2006; Kuroedov et al., 2004; Van Bortel and Van Baak, 1992). It is additionally recommended that new studies be conducted involving other third-generation $\mathrm{BB}$, such as carvedilol and nebivolol, to determine if there are similar differences in the heart rate decrease, as well as to verify the negative chronotropic effect at various points in the day.

This study used doses of 25, 40 and $50 \mathrm{mg}$. However, because of the small sample size, it was not possible to correlate dose with chronotropic response. Further studies using a larger sample size are warranted to verify this correlation.

These finding emphasize that the chronotropic change phenomenon demonstrated by the beta-blockers should be studied in order to guarantee exercise prescription accuracy and quality among the large hypertensive population in use of this drug as part of their anti-hypertensive therapies.

\section{CONCLUSION}

By confirming the small positive chronotropic effect induced by the BB, this study reinforces the need for heart rate correction among hypertensive users of $\mathrm{BB}$, as suggested by Brazilian Society of Cardiology. Nevertheless, the data obtained revealed that this chronotropic effect is significantly weaker after the plasmatic half-life period, and that exercise prescriptions must consider the time interval between $\mathrm{BB}$ administration and time of exercise activity.

\section{REFERENCES}

BASTER, T.; BASTER-BROS, C. Exercise and hypertension. Aust. Fam. Physician, v.34, n.6, p.419-424, 2005.

COUTO, A. A. Farmacologia cardiovascular aplicada à clínica. Rio de Janeiro: Editora Revinter, 1998. 315 p.

DERMAN, W. E.; DUNBAR, F.; HAUS, M.; LAMBERT, M.; NOAKES, T. D. Chronic beta-blockade does not influence muscle power output during high-intensity exercise of shortduration. Eur. J. Appl. Physiol. Occup. Physiol., v.67, n.5, p.415-419, 1993.
FIMIRDA, C. C.; MESQUITA, E. T. O paradoxo do tratamento da ICC com betabloqueadores: implicações para pacientes hipertensos. Rev. Bras. Hipert., v.8, n.4, p.458-465, 2001.

KARVONEM, M. J.; KENTALA, E.; MUSTALA, O. The effects of training on heart rate: a longitudinal study. Ann. Méd. Exper. Fenn., v.35, n.3, p.307-315, 1957.

KOSHUCHAROVA, G.; ZWEIKER, R.; MAIER, R.; LERCHER, P.; STEPAN, V.; LEIN, W.; STOSCHITZKY, K. Different beta-blocking effetcs of carvedilol and bisoprolol in humans. J. Clin. Basic Cardiol., v.4, n.53, p.53-56, 2001.

KUROEDOV, A.; CONSENTINO, F.; LUSCHER, T. F. Pharmacological mechanisms of clinically favorable properties of a selective beta1-adrenoceptor antagonista nebivolol. Cardiovasc. Drug Rev., v.22, n.3, p.155-168, 2004.

NELSON, M. I. E.; REJESKI, W. J.; BLAIR, S. N.; DUNCAN, P. W.; JUDGE, J. O.; KING, A. C.; MACERA, C. A.; CASTANEDA-SCEPPA, C. Physical activity and public health in older adults: recommendation from the American College of Sports Medicine and the American Heart Association. Med. Sci. Sports Exerc., v.39, n.8, p.14351445, 2007.

NÓBREGA, C. L.; FREITAS, E. V.; OLIVEIRA, M. A U. B.; LEITÃO, M. B.; LAZZOLI, J. K.; NAHAS, R. M.; BAPTISTA, C. A. S.; DRUMMOND, F. A.; REZENDE, L.; PEREIRA, J.; RADOMINSKI R, B.; PINTO, M. L. N.; THIELE, E. S.; HERNANDEZ, A. J.; ARAÚJO, C. G. S. O.; TEIXEIRA, J. A. C. Posicionamento oficial da Sociedade Brasileira de Medicina do Esporte e da Sociedade Brasileira de Geriatria e Gerontologia: atividade física e saúde no idoso. Rev. Bras. Med. Esporte, v.5, n.6, p.207211, 1999.

PEDERSEN, M. E.; COCKCROFT, J. R. The vasodilatory betablockers. Curr. Hypertens. Rep., v.9, n.4, p.269-277, 2007.

PEREIRA-BARRETO, C. A. Por que, como e quando usar os betabloqueadores no tratamento da insuficiência cardíaca. Rev. Soc. Bras. Cardiol. E. São Paulo, v.14, n.1, p.134-146, 2004.

POKAN, K.; HUONKER, M.; LEHMANN, M.; DICKHUTH, H. H.; KEUL, J. Effect of beta blockade on hemodynamics in physical exertion. Wien Med. Wochenschr., v.140, n.6/7, p.178-184, 1999. 
ROBERGS, R. A.; LANDWEHR, R. The surprising history of the "HRmax $=220$ - idade equation. J. Exerc. Physiol., v.5, n.2, p.1-10, 2002.

SOCIEDADE BRASILEIRA DE CARDIOLOGIA. I Consenso nacional de reabilitação cardiovascular. Arq. Bras. Cardio., v.69, n.4, p.267-291, 1997.

SOCIEDADE RASILEIRA DE CARDIOLOGIA. V Diretrizes Brasileiras de Hipertensão Arterial. Rev. Soc. Bras. Hipert., v.9, n.4, p.5-48, 2006.

STOSCHITZKY, K.; STOSCHITZKY, G.; KLEIN, W.; MULLER, F.; BUHRING, K.; LAMPRECHT, G.; LINDNER, W. Different effects of exercise on plasma concentrations of nebivolol, bisoprolol and carvedilol. Cardiovasc. Drugs Ther., v.18, n.2, p.135-138, 2004.

STOSCHITZKY, K.; STOSCHITZKY, G.; HELMUT, B.; BONELLI, C. Comparing beta-blocking effects of bisoprolol, carvedilol and nebivolol. Cardiology, v.106, n.4, p.199-206, 2006.

SUZUKI, S.; OHTA, T. Exercise therapy for the patients with mild hypertension. Nippon Rinsho., v.66, n.8, p.1553-1559, 2008.

TABET, J. Y.; MEURIN, P.; BEN DRISS, A.; THABUT, G.; WEBER, H.; RENAUD, N.; ODJINKEM, N.; SOLAL, A. C.; Determination of exercise training heart rate in patients on beta-blockers after myocardial infarction. Eur. J. Cardiovasc. Prev. Rehabil., v.13, n.4, p.538-543, 2006.

TESCH, P. A. Exercise performance and beta-blockade. Sports Méd., v.2, n.6, p.389-412, 1985.
THOMPSON, P. D. O exercício e a cardiologia do esporte. Barueri: Manole, 2004. 485 p.

VAN BAAK, M. A. Beta-adrenoceptor blockade and exercise. Sports Méd., v.5, n.4, p.209-225, 1988.

VAN BORTEL, L. M. E.; VAN BAAK, M. A. Exercise tolerance with nebivolol and atenolol. United Satates of America. Cardiovasc. Drugs Ther., v.6, n.3, p.239-247, 1992.

VANZELLI, A. S.; BARTHOLOMEU, B. J.; MATTOS, L. N. J.; BRUM P. C. Prescrição de exercício físico para portadores de doenças cardiovasculares que fazem uso de betabloqueadores. Rev. Soc. Cardiol. E. São Paulo, v.15, n.2, p.10-16, 2005.

VEVERKA, A.; NUZUM, D. S.; JOLLY, J. L. Nebivolol: a thirdgeneration beta-adrenergic blocker. Ann. Pharmacother. v.40, n.7/8, p.1353-1360, 2006

WEISS, R. Nebivolol: a novel beta-blocker with nitric oxideinduced vasodilatation. Vasc. Health Risk Manag., v.2, n.3, p.303-308, 2006.

WONISCH, M.; HOFMANN, P.; FRUHWALD, F. M.; KRAXNER, W.; HÖDL, R.; POKAN, R.; KLEIN, W. Influence of beta-blocker use on percentage of target heart rate exercise prescription. Eur. J. Cardiovasc. Prev. Rehabil., v.10, n.4, p.296-301, 2003.

Received for publication on $09^{\text {th }}$ September 2008 . Accepted for publication on $30^{\text {th }}$ March 2009. 
